\title{
Organizational Identity in the Digital Era
}

\author{
Axel Hund \\ Neu-Ulm University of \\ Applied Sciences, \\ axel.hund@hnu.de
}

\author{
Heinz-Theo Wagner \\ Neu-Ulm University of \\ Applied Sciences \\ heinz-theo.wagner@hnu.de
}

\author{
Daniel Beimborn \\ University of Bamberg \\ daniel.beimborn@uni- \\ bamberg.de
}

\author{
Tim Weitzel \\ University of Bamberg \\ tim.weitzel@uni- \\ bamberg.de
}

\begin{abstract}
The perception of an organization is largely based on its identity, which determines how it is expected to act. Yet, digital technology often creates situations where organizations experience conflicting demands from different stakeholders. Over time, organizations are therefore forced to take actions that may not be consistent with their identity and mission, and must find ways to pursue multiple - sometimes conflicting - goals simultaneously. Our study examines how organizations frame their identity and discusses how different framings may help addressing different needs while remaining consistent with the initial identity. Our findings allow us to contribute to extant literature by: (1) Identifying differences in the framing of organizational identities with regard to focus on Purpose, Strategic Boundaries, Value Propositions, and Value Statements. (2) Discussing the implications of our findings for the current literature dealing with the "identity-challenging" nature of digital technology. (3) Outlining promising research questions for future research.
\end{abstract}

\section{Introduction}

In 1974, Peter Drucker suggested that organizations benefit from explicitly stating their core purpose [1]. With it, the idea of mission statements was born and has been an important feature of most companies ever since as a valuable tool for organizations to "manage their identity and image" [2, p. 429]. As of today, mission statements are among the most popular management tools for almost two decades [3]. In the most general sense, "[...] a mission statement is a formal written document intended to capture an organization's unique raison d'être. It should answer such vital questions as: why do we exist, what is our real purpose and what are we trying to accomplish" [4, p. 360]. Hence, an "organization's mission serves as a sociocognitive bridge between its identity and its actions by specifying why the organization should exist and how it should act" [5, p. 819].

To better understand how the organizational identity, defined as organizational "members' shared beliefs about the distinctive, central, and relatively enduring attributes of the organization" [6, p. 327], can be captured and communicated within its' mission statement, research typically focuses on components of effective mission statements and how they relate to the overall performance of an organizations. For example, by examining the mission statements of large organizations, David [7] identify nine components and developed guidelines for creating an effective mission statement. The identified components have since been tested and linked to financial performance [e.g., 8]. Furthermore, by publicly committing to a specific identity and goals, an organization signals a standard to internal and external stakeholders by which its reputation will be judged [9]. Companies that are not living up to their proclaimed mission are in danger of severely damaging their overall reputation [10]. Thus, companies have a strong motivation to stick to their mission statements and 'walk the talk' $[11,12]$. Yet, in light of the digital transformation, which is characterized by rapid changes for individuals as well as entire societies [13], organizations must find ways to dynamically align their actions to altered circumstances. This is particularly visible in the context of digital innovation, where organizations typically must find ways to collaborate with multiple innovation actors within large innovation networks [14] that operate across numerous industries under different sets of regulations [15] and are pursuing diverging - even conflicting - goals [16,17]. Even the use of digital technology in itself can lead to paradoxical situations [18]. Over time, organizations therefore face situations which require actions that might not be in line with their established identity and mission (e.g., [5]) and must find ways to alter their identity in order to harness the opportunities offered by novel digital technologies [19]. Eventually, this can even lead to the development of diverging identities across different parts of an organization [20].

However, so far we have limited insight into how organizations manage their identity in the context of conflicting demands associated with digital technology (e.g., $[13,21])$, which is why we need "more clarity about the nature of organizational mission(s), [...] and under what conditions such missions increase alignment between organizational actions and organizational identities" [22, p. 235]. Particularly the 'identity-challeng- 
ing' nature of digital technology [19] provides an interesting opportunity for IS research to better understand "how organizations manage the pressures that are associated with pursuing multiple goals" [20, p. 230]. As a first step to address this issue by investigating how leading organizations from the IT industry, which are pioneers in dealing with identity-changing digital technology, frame and communicate their identity and mission in comparison to their direct competitors. Our research question is therefore:

\section{How do leading organizations within the IT industry frame their identity and mission?}

To answer the research question we will first provide an overview of extant literature. We then present how we collected and analyzed data in form of mission statements from highly innovative companies and less innovative competitors in the IT industry to uncover prevalent topics. Building on our findings, we then discuss the identified differences in the way organizations frame their identity and the implications for identity management in times of rapidly changing circumstances due to digital innovation and digital transformation.

\section{Theoretical Background}

Literature concerned with 'digital' phenomena such as digital innovation and digital transformation underscores the rapid changes caused by digital technology. For example, new products that are created through the combination of physical and digital components, now have a layered modular product architecture [23]. This new product architecture has strong implications for organizations and challenges existing assumptions about organizational design and strategy $[24,25]$.

In an effort to respond to the altered circumstances due to digitalization, organizations must redefine their identity [21], which is oftentimes met with internal and external resistance [13]. Internally, changes are met with inertia and path dependence, which hinders effective responses to new digital technologies [26]. Furthermore, an organization might not even recognize the potential of an 'identity-changing' digital technology, if the existing identity hinders explorative behavior [19]. Externally, organizations must expect negative reactions for actions that are not in line with the established identity and mission [9]. Interestingly, this development indicates that: "[...] Drucker's [1] original recommendation that a mission should be a simple statement of purpose has either been supplemented or replaced with the mission as a marketing or public relations tool directed at stakeholders" [10, p. 207-208]. This trend is underscored by the fact that most organizations are not only including their vision and mission but also address one or more stakeholders directly in their mission statement [27].

Moreover, while mission statements are a nearly ubiquitous feature of most organizations [8], there exist various labels since every organization accentuates different topics in their mission statement. Alternative labels include 'guiding principles', 'core values', 'vision statements' or 'corporate philosophy' $[2,28]$. Striving to systemize these differences, Braun et al. [29] identified three core aspects: vision (statements about future goals and development), mission (statements about an organization's raison d'être), and values (statements about the core philosophy). For this article, we include all three aspects when referring to mission statements. Since organizations are acting strategically when developing a mission statement [30], mission statements provide an interesting opportunity to better understand how organizations manage their identity (e.g., [5]). To do so, we build on a meta-analysis by Desmidt et al. [31] who put forward four potential ways of operationalizing the mission statements: Clear definition of purpose, clear delineation of strategic boundaries, clarification of the organization's value proposition, and clear value statement. In the following, we first provide more details about our data collection and then present our analysis.

\section{Research Design}

\subsection{Data Collection}

In order to uncover differences between mission statements of highly innovative vs. less innovative organizations, we first had to identify two comparable sets of firms. For this, we searched through established innovation rankings. Building upon the insights of established rankings is common practice in mission statement research since it allows to link mission statement characteristics to outcomes such as organizational practices and performance measures (e.g., [2,8]).

We identified the 2018 Global Innovation 1000 Study (GI) by Strategy\& as particularly fitting to explore differences between highly innovative and their competitors. The ranking is conducted annually since 2005 and has already been used by several other scientific publications across disciplines (e.g., [32,33]). For our study, we use the GI ranking of 2018. Following best practices in extant literature [2], we selected one of the ten industry sectors defined in the GI study - information technology (IT) - in order to control for variance between different industry sectors. All of the companies are for-profit (since context was identified by Braun et al. [29] to be an important distinction in terms of mission). Furthermore, since the GI ranking only considers publicly traded companies that publish their R\&D 


\begin{tabular}{|c|c|}
\hline $\begin{array}{l}\text { Highly Innovative } \\
\text { Organizations }\end{array}$ & $\begin{array}{l}\text { Competitor } \\
\text { Organizations } \\
\end{array}$ \\
\hline $\begin{array}{l}\text { Alphabet, Samsung, In- } \\
\text { tel, Microsoft, Apple, Fa- } \\
\text { cebook, Oracle, Cisco, } \\
\text { Nokia, Qualcomm, Erics- } \\
\text { son, SAP, Alibaba, } \\
\text { Broadcom, Hitachi, } \\
\text { Canon, Hon Hai Preci- } \\
\text { sion Industry, Taiwan } \\
\text { Semiconductor Manufac- } \\
\text { turing Company } \\
\text { (TSMC), Tencent Hold- } \\
\text { ings Limited, Western } \\
\text { Digital Corporation, ZTE } \\
\text { Corporation, Baidu, Inc., } \\
\text { Media Tek Inc. }\end{array}$ & $\begin{array}{l}\text { YY Inc., Qisda Corpora- } \\
\text { tion, ASM International } \\
\text { NV, TOTVS SA, Advan- } \\
\text { tech Do., Ltd, Twilio Inc., } \\
\text { Nemetschek SE, ADVA } \\
\text { Optical Networking, Rib- } \\
\text { bon Communications, CSG } \\
\text { Systems International, Inc., } \\
\text { Maxi Linear, Calix Inc., } \\
\text { Fair Isaac Corp., Mer- } \\
\text { cadoLibre Inc., Ambarella } \\
\text { Inc., Largan Precision, } \\
\text { S\&T AG, Laird PLC, } \\
\text { GoGo Inc., Jiangsu } \\
\text { Changjiang Electronics } \\
\text { Technology, Adtran, } \\
\text { Autohome Inc. }\end{array}$ \\
\hline
\end{tabular}

spending, we automatically exclude privately held organizations. This is necessary to ensure that stakeholder and regulatory conditions are equal and comparable. The IT industry was chosen because there is an especially high variance in innovativeness. On the one hand, five of the ten most innovative companies worldwide belong to the IT sector; on the other hand, there are also numerous companies with ranking positions far down the road. Furthermore, since pervasive digitalization has changed the way how mission statements are used and communicated [4] we decided to focus on the IT industry because there are companies that are not only highly successful in terms of innovativeness but also in terms of leveraging digital technology (e.g., Google, Apple, Facebook).

To identify differences between highly innovative and less innovative organizations, we compiled a sample of the 25 most innovative organizations in the IT industry and identified their lowest performing, direct competitor by taking different industry subgroups (e.g., semiconductor, software/services, hardware) within the IT industry into account. Subsequently, we searched publicly accessible outlets such as the organization's website and annual reports to identify their respective mission statement. We choose to rely only on publicly accessible mission statements because: "[...] organizational leaders who do not explicitly publicize them are less likely to be held accountable to them by internal and external stakeholders" [2, p. 434]. As discussed earlier, we follow extant research and also include statements that were labelled differently, such as 'guiding principles', 'core values', 'vision statements' or 'corporate philosophy' $[2,28]$. In total, we were able to identify mission statements for 23 of the 25 highly innovative companies and 22 of the 25 competitor companies, which are according to the GI study less innovative in
average.Table 1 depicts an overview about the highly innovative companies in our sample and their position in the GI ranking:

\section{Table 1. Sample of Publicly Traded Companies 3.2. Data Analysis}

To analyze the content of the mission statement, we first read various public statements as well as parts of the organization's annual reports and website. After gaining a better understanding of the organizational context, we conducted a qualitative analysis as described by Mayring and Fenzl [34]. First, we developed a deductive category system along the four categories identified in the meta-review by Desmidt et al. [31]. These categories are sufficiently distinct to allow the development of concise, nominal coding guidelines as depicted in Table 2:

Table 2. Coding Guideline (Desmidt et al. [34])

\begin{tabular}{|l|l|}
\hline Category Definition & $\begin{array}{l}\text { Anchoring } \\
\text { Example }\end{array}$ \\
\hline $\begin{array}{l}\text { Definition of Purpose: State- } \\
\text { ment provides a sense of the } \\
\text { organization's direction and } \\
\text { purpose. Related to formula- } \\
\text { tion and understanding of or- } \\
\text { ganizational short- and long- } \\
\text { term goals. }\end{array}$ & $\begin{array}{l}\text { "At SAP our purpose } \\
\text { better and improve } \\
\text { people's lives." (SAP) }\end{array}$ \\
\hline $\begin{array}{l}\text { Strategic Boundaries: State- } \\
\text { ment focuses on the alloca- } \\
\text { tion of organizational re- } \\
\text { sources. Related to improved } \\
\text { decision-making processes } \\
\text { and better resource allocation. }\end{array}$ & $\begin{array}{l}\text { "Our strategy is to } \\
\text { continue to attract and } \\
\text { retain automobile con- } \\
\text { sumers by enhancing } \\
\text { our user engagement." } \\
\text { (Autohome Inc.) }\end{array}$ \\
\hline $\begin{array}{l}\text { Value Propositions: State- } \\
\text { ment aims at communicating } \\
\text { organizational value proposi- } \\
\text { tions to internal and external } \\
\text { stakeholders. Related to gain- } \\
\text { ing support from stakeholder } \\
\text { and sharing knowledge about } \\
\text { the proclaimed values. }\end{array}$ & $\begin{array}{l}\text { "We provide the tech- } \\
\text { nology infrastructure } \\
\text { and marketing reach to } \\
\text { help merchants, brands } \\
\text { and other businesses to } \\
\text { leverage the power of } \\
\text { new technology [...]" } \\
\text { (Alibaba) }\end{array}$ \\
\hline $\begin{array}{l}\text { Value Statement: Statement } \\
\text { aims at inspiring organiza- } \\
\text { tional members to identify } \\
\text { with the organizational values } \\
\text { and to be guided by them. Re- } \\
\text { lated to the establishment of a } \\
\text { sense of mission among the } \\
\text { staff. }\end{array}$ & $\begin{array}{l}\text { "Integrity is our most } \\
\text { basic and most im- } \\
\text { portant core value. We } \\
\text { tell the truth. We be- } \\
\text { lieve that the record of } \\
\text { our accomplishments } \\
\text { is the best proof of our } \\
\text { merit." (TWSC) }\end{array}$ \\
\hline
\end{tabular}

Guided by these coding guidelines, we went through each mission statement and coded for segments that refer to one or more of the deductively established categories. A segment can be thought of as a part of a mission statement that makes a specific statement. We 
allotted each identified segment to the respective category using MaxQDA2020. If a segment addressed several categories, we coded it accordingly. Initially we only went through one third of the mission statements and subsequently discussed the results among the authors. This was done to uncover any diverging interpretations and to ensure a shared understanding. After clarifying any conflicting interpretations, we proceeded with the remainder of the dataset. In a second step, after categorizing each segment to one or several of the deductive categories, we carefully went through each of the categories and coded inductively for emerging subcategories. Inductive coding for subcategories is in line with established best-practices in literature (e.g., [34]) and enables the identification of trends within each category. Hence, we are able to take a more granular look on the components of each mission statement. In the next section, we will present our findings in detail.

\section{Findings - Different Identity Framings}

In total, we identified and coded 371 segments of which 212 are from highly innovative companies and 159 from their less-innovative competitors. Table 3 depicts how many segments were identified for each category. At this level of the analysis, a first clear pattern emerges: on average, highly innovative firms refer more often to clear Definition of Purpose and clear Value Statements, whereas their less innovative counterparts refer slightly more to clear Delineation of Strategic Boundaries and Value Proposition. In the following sections, the findings for each subcategory are presented in detail.

\section{Table 3. Identified Segments per Category}

\begin{tabular}{|c|c|c|c|}
\hline $\begin{array}{l}\text { Cate- } \\
\text { gory }\end{array}$ & \begin{tabular}{|l|} 
Innovator \\
vs. \\
Competitor
\end{tabular} & $\begin{array}{l}\text { Identified } \\
\text { Subcategories }\end{array}$ & $\begin{array}{l}\text { Identified } \\
\text { \#Segment }\end{array}$ \\
\hline \multirow{4}{*}{$\begin{array}{l}\text { Defini- } \\
\text { tion of } \\
\text { Purpose }\end{array}$} & \multirow{4}{*}{21 vs. 12} & Focus & 45 \\
\hline & & Realistic vs. Audacious & 28 \\
\hline & & Inclusive vs. Focused & 26 \\
\hline & & $\begin{array}{l}\text { Altruistic vs. Competi- } \\
\text { tive }\end{array}$ & 17 \\
\hline \multirow{2}{*}{$\begin{array}{l}\text { Strategic } \\
\text { Bounda- } \\
\text { ries }\end{array}$} & \multirow[b]{2}{*}{6 vs. 12} & Strategic Guidance & 37 \\
\hline & & Aim of Investment & 13 \\
\hline \multirow{3}{*}{$\begin{array}{l}\text { Value } \\
\text { Proposi- } \\
\text { tions }\end{array}$} & \multirow{3}{*}{16 vs. 17} & Signaling & 38 \\
\hline & & Products and Services & 30 \\
\hline & & $\begin{array}{l}\text { Information about } \\
\text { Company }\end{array}$ & 18 \\
\hline \multirow{4}{*}{$\begin{array}{l}\text { Value } \\
\text { State- } \\
\text { ment }\end{array}$} & \multirow{4}{*}{17 vs. 10} & Ethics & 44 \\
\hline & & Orientation & 26 \\
\hline & & Innovativeness & 20 \\
\hline & & Employees & 20 \\
\hline
\end{tabular}

\subsection{Definition of Purpose}

The first category Definition of Purpose is also the most prevalent one. Segments were allotted to this category if they provide a sense of the organization's direction and purpose. Such definitions are intended to help define and formulate organizational short-term and long-term goals [31]. Interestingly, the mission statements of highly innovative companies (87 identified segments) refer more often to Definition of Purpose than the statements of their less innovative competitors (37 identified segments).

Focus. The most dominant subcategory concerns the specification of an organizational focus: 21 highly innovative companies and 12 competitor companies explicitly state a specific focus, typically underscoring the importance of technology, innovation or social and technological connectivity. For example, Baidu understands itself as "[...] a technology-based media company [...]" and Intel pledges to "Utilize the power of Moore's Law [...]". Thirteen of the highly innovative companies state a focus on technology, whereas only five of the competitors do so. Furthermore, there is a strong tendency to accentuate the importance of innovation. Ericsson for example, marries a focus on technology with a focus on innovation and good citizenship by stating: "Our purpose is to innovate technology for good". Here, six of the highly innovative companies and three of the competitor companies put forward a focus on innovation. Additionally, connectivity emerged as a central topic in several mission statements. Here, some organizations have a focus on social connectivity and want to bring "the world closer together" (e.g., Canon; Facebook). Others focus on the technological component of connectivity: "[...] we create the technology to connect the world" (Nokia).

Realistic vs. Audacious. During the analysis different types of goals stated as part of the organizational purpose emerged. We differentiate between rather realistic goals, which would be perceived as specific for an external observer, vs. rather audacious, unspecific goals, which may sound hard to accomplish. In total, there are six highly innovative and seven competitor companies with rather specific and realistic goals. For example, Autohome Inc. describes its mission as: "Our mission is to engage, educate and inform auto consumers in China with everything they need to know about buying, using and selling cars". Thus, the stated goal includes a defined customer group (auto consumers) within a specific geographic area (China) and a clear roadmap to reach the declared goal (providing information about buying, using and selling cars). In stark contrast, we also found rather unspecific, highly audacious goals such as in the current mission statement of Microsoft: "We believe in 
what people make possible. Our mission is to empower every person and every organization on the planet to achieve more". The purpose does not define any restrictions in e.g., customer group, market, or product offering but rather puts forward an ideal. Interestingly, while we were able to identify roughly equal amounts of realistic goals between innovative and competitor companies, the distribution of audacious goals is rather onesided (eleven highly innovative companies vs. one competitor company).

Inclusive vs. Focused. There are differences as to who is addressed by the organizational purpose. We identified two main types: The first type is rather inclusive, meaning that the mission statement is not restricted and addresses everyone. In total, 19 companies include everyone into their stated mission. For example, Calix Inc. states that: "Our Mission is to connect everyone and everything”. Interestingly, only four competitor companies have an inclusive focus, whereas fifteen of the highly innovative companies include everyone into their stated mission/purpose. The second type is more focused, meaning that the mission statement clearly defines who is addressed. Such mission statements typically aim at specific groups such as customers, employees, investors, or partners. An example is the mission statement of TOTVS SA: "Our raison d'être is to enable our Clients to be more successful in their segments [...]". In total, we found seven companies that clearly define who is addressed by their organizational purpose (three highly innovative companies and four competitor companies).

Altruistic vs. Competitive. There are also differences in the way organizations perceive their purpose. We distinguish between an altruistic perception and a competitive perception. 13 companies express an altruistic tendency, such as Samsung who state their purpose is to "Inspire the world with our innovative technologies, products and design that enrich people's lives and contribute to social prosperity by creating a new future". In total, 11 highly innovative companies and two competitor companies had rather altruistic elements in their mission statements. In terms of a competitive perception, we identified four companies. For example, Autohome Inc. states: "Our goal is to become the dominant player in China's online automotive advertising market". Thereby, the statement accentuates a competitive mindset.

\subsection{Strategic Boundaries}

The second category Strategic Boundaries focuses on the allocation of organizational resources, aiming at improving decision-making processes and enabling better resource allocation. In total, there are 4 segments of highly innovative companies and 36 segments from their competitor companies.

Strategic Guidance. Statements regarding Strategic Boundaries typically focus on a specific product, service, or market. An example is Mercado Libre: "Our main focus is to deliver compelling technological and commercial solutions that address the distinctive cultural and geographic challenges of operating an online commerce and payments platform in Latin America". Furthermore, the encouragement of strategic partnerships is mentioned. For example, Tencent states that "[...] forging strategic partnerships with a range of industries" is beneficial for innovation. Additionally, several companies underscored the importance of being a profitable, competitive company. For example, Qisda Corporation sets the goal of generating "[...] a healthy corporate profit". In general, companies accentuate important topics to provide strategic guidance when ambiguous decisions have to be made.

Aim of Investments. Strategic boundaries also specify the aim of investments. Here, there appear to be differences about an internal and external orientation. For example, Apple focuses on internal innovativeness: "The Company believes ongoing investment in research and development ("R\&D"), marketing and advertising is critical to the development and sale of innovative products, services and technologies". Nemetschek SE, on the other hand, focuses on the acquisition of external expertise: "[...] good acquisition opportunities to generate further growth".

\subsection{Value Propositions}

The third category Value Propositions is about communicating organizational value propositions to internal and external stakeholders. Such statements aim at gaining support from stakeholders and sharing knowledge about the organization. In total, there are 86 segments with 38 segments coming from highly innovative companies and 48 segments from competitor companies.

Signaling. The most prominent form of clarifying value propositions is through different forms of signaling. The first form focuses on the relevance of the company. For example, "For more than 20 years, Gogo has been synonymous with better ways of connecting in flight" (GoGo Inc.). The second form highlights a strong customer orientation with statements such as "The Company is committed to bringing the best user experience to its customers [...]" (Apple) or "Guided by its "user oriented" business philosophy [...]" (Tencent). The third form signals strong innovation performance through statements such as "We have delivered world best products and services through passion for innovation [...]" (Samsung). The fourth form signals high 
transparency and integrity through statements such as "Improving the transparency and oversight of what we're doing" (Alphabet).

Products and Services. Another strong pattern emerges regarding statements about the products and services of a company. Companies clarified the value propositions of their offerings through statements such as "We provide the technology infrastructure and marketing reach to help merchants, brands and other businesses to leverage the power of new technology" (Alibaba). Another example is: "Tencent also provides cutting-edge financial technology and seamless mobile payment solutions that are helping support the development of smart cities, smart transport and smart retail" (Tencent).

Information About the Company. Moreover, the analyzed mission statements contained 18 segments from 17 companies that communicate information about the organization. Mostly, companies communicated their goals through statements such as "Ericsson are on the quest for easy, creating game-changing technology that's easy to use, adopt and scale" (Ericsson) or specified their organizational structure e.g., through "The Media Tek board delegates various responsibilities and authority to two Board Committees, Audit Committee and Remuneration Committee to supervise the company effectively" (Media Tek). In total, we uncovered statements that contain information about the company from nine highly innovative companies and eight competitor companies.

\subsection{Value Statements}

The fourth and last category Value Statement is about inspiring organizational members to identify with the organizational values and to be guided by them. Such declarations of organizational values are intended to establish a sense of mission among the staff [31]. In total, we identified 110 segments. There are five subcategories of value statements: Ethical, Orientation, Employees, Innovation, Pioneering. Interestingly, the mission statements of highly innovative companies (72 identified segments) include more value statements than the statements of their less innovative competitors (38 identified segments).

Ethics. The most dominant subcategory revolves around ethical values. In total, there are 44 codings from 22 companies. Companies herald accountability and integrity through statements such as "Integrity is our most basic and most important core value. We tell the truth" (TWSM). Another important aspect of ethical values focuses on corporate citizenship and community. Companies underscore their responsibility for it through statements such as: "Strengthen social responsibility and global citizenship [...]" (Broadcom) or "Truly global companies must foster good relations with customers and communities, as well as with governments, regions and the environment as part of their fulfillment of social responsibilities" (Canon). Moreover, ten companies specifically state that they value inclusiveness and diversity. "It conveys our dedication to seeing all people, regardless of culture, customs, language or race, harmoniously living and working together in happiness into the future" (Canon).

Orientation. Another strong pattern emerges with regard to the different orientations of the organizational values. The first pattern puts the customer in the center of attention. For example, Oracle states: "Customer Satisfaction: Oracle employees consistently treat customer satisfaction as a top priority". The second pattern is about enabling win-win situations. For example, Hon Hai states: "[...] achieve a win-win model for all stakeholders including shareholders, employees, community and management". The third pattern is about a stronger emphasis on continuous improvement. For example, Nokia states: "[...] striving for continuous improvement" and "constantly refine our skills, learn and embrace new ways of doing thing, and adapt to the world around us". In total, there are statements regarding the orientation of organizational value statements from ten highly innovative companies and five from their competitor companies.

Innovativeness. Furthermore, several companies highlight innovativeness within their value statements. For example, YY Inc. states that "We create an environment where people are encouraged to demonstrate innovation by implementing new ideas" or Tencent put forward they are "[...] passionate about improving people's quality of life through digital innovation". A special emphasis was put on a proactive (Canon) and pioneering spirit (Hitachi). In total, we uncovered statements regarding innovativeness from twelve highly innovative companies and four from their competitor companies.

Employees. Companies also include direct statements to or about their employees. Most commonly, they refer either to what is expected from employees in terms of high standards, ambitions or skills or they highlight the value of their employees. High standards are communicated either in general through statements such as "The Board of Directors of Ambarella (the "Company") sets high standards for the Company's employees, officers and directors" (Ambarella) or with an emphasis on specific areas such as skills, skills or character. A typical statement for a specific area would be "When selecting new employees, we place emphasis on the candidates' qualifications and character, not connections or access" (TWSC). Another way companies include their 
employees in their values is through expressing appreciation such as "It is through our people and culture that we shape technology to serve human needs" (Nokia) or by putting forth opportunities such as "[...] provide employees with the opportunity to learn and develop" (YY Inc.).

\section{Discussion}

Our study started by noting that digital technology create situations in which organizations experience contradicting demands from different internal and external stakeholder groups (e.g., [18,21]). Therefore, organizations find themselves in situations that require taking actions that might not be in line with their established identity as described in their mission statement [2] and search for ways to accommodate multiple - sometimes conflicting - missions simultaneously [5]. Yet, by acting against their proclaimed mission, organizations jeopardize their overall reputation $[9,10]$. To gain deeper insights into the different approaches that organizations take to manage the 'identity-challenging' nature of digital technology [19], we posed the following question: How do leading organizations within the IT industry frame their identity and mission? We answer this question by analyzing the mission statements of highly innovative organizations and less innovative competitors in the IT industry to uncover differences and similarities about how organizations define their identity along the categories of Purpose, Strategic Boundaries, Value Propositions and Value Statements (c.f. [31]) as displayed in Table 3.

Our results indicate that highly innovative companies frame their mission and identity with a stronger focus on purpose and values. Their less innovative competitors, on the other hand, frame their mission and identity with a stronger focus on strategic boundaries, as well as on their organizational value propositions. Interestingly, our results partly contradict the existing literature on mission statements. Bart [35] also examines the mission statements of innovative and non-innovative organizations and finds that the differences mainly manifest themselves in more specific statements about, for example, competitive strategy, behavioral norms, financial goals, technology, and survival, but does not find differences in regard to concerns for employees, shareholders, and customers. Our results differ in part because we find that highly innovative organizations often have less specified mission statements, and also because we find indications for a stronger customer focus in highly innovative organizations. We are, thereby, more in line with another study by Bart [36, p. 554], in which it is stated that: "[...] mission content seems to matter: especially the degree to which a firm specify its 'concern for customer satisfaction"'. These differences point us towards the impact of digital technology, which requires a stronger focus on customers and users, up to their integration into the innovation process $[37,38]$. Therefore, the pre-digital context in which the results of Bart [35] were produced must be taken into account. Hence, our study addresses inconsistencies in the existing literature and provides additional insights into the importance of customer orientation in mission statements. Most importantly, our study draws upon an interesting lens - organizational identity - to investigate the oftentimes conflicting situations caused by digital technology (e.g., $[18,21]$ ) and takes a first step to understanding different approaches to managing identity and mission in an environment that is increasingly shaped by digital technology [39]. In the following, we discuss these insights in the light of extant literature concerned with 'digital phenomena'.

Current research on 'digital phenomena' highlights the flexible and agnostic nature of digital technology [40], which allows the identification of unforeseen use scenarios for organizations and users alike (e.g., $[23,37])$. These use scenarios oftentimes transcend the traditional boundaries of organizations [41], products [23], and even industries [15]. Thereby, digital technology leads inevitably to the convergence of: "[...] previously separate industries. For example, Skype, a software development firm, now competes directly with traditional telecommunication companies in international and long-distance markets" [25, p. 1399]. Our results indicate a tendency among innovative companies to remain rather ambiguous about their defined goals, which are typically bold but unspecific and do not specify any products or industries. Organizational identities based on bold but unspecific goals have been discussed before as a powerful tool to encourage progress [42]. Particularly in an increasingly digitalized environment, which is characterized by converging industries [15,25] and products $[17,23]$ refraining from clearly defining specific industrial boundaries or products could help embracing the rather emergent, never fully finished nature of digital technology $[23,41]$. Not defining a priori what industry and product an organization is aiming at might even enables more agile approaches to strategy-making, which has been identified as critical for digital innovation [43]. Furthermore, the unspecific nature of the identified goals potentially also broadens the awareness of new contexts in which existing patterns can be reused as described by Henfridsson et al. [44]. Thereby, organizational identities that are not tied to specific industries or products enable the identification of new, unforeseen opportunities since insights "from the industry and technological environment [...are] noticed and filtered through the lens of the firm's identity" [19, p. 447]. Since digital technology is agnostic and can be reused 
in and repurposed to several contexts [23], the ability to detect newly arising needs and contexts is highly relevant. This notion is underscored in literature by the increasing attention for serendipity, which is the discovery of "[...] a new solution and assess it to be worth adopting although the "problem" it would address had not previously been in mind as an object of search or even awareness" [45, p. 207]. Thus, an organizational identity, which highlights clear strategic boundaries, might hinder the effective identification of new opportunities beyond already established contexts.

Furthermore, to benefit from the described convergence, an organizations' identity must foster and value the exploration of new and diverse inputs. In the category Value Statements we find a tendency amongst innovative companies to accentuate the merit of diversity and diverse inputs more prominently than their competitors. This is in line with extant research, which states that diversity is linked to improved performance but also highlights that diverse groups must perceive diversity as positive in order to reap the benefits [46]. In other words, diverse backgrounds and insights can be used most efficiently if group members perceive the diverse input as beneficial [46] and work towards a creative synthesis of the diverse resources [47]. Particularly in the context of digital innovation networks, which span multiple innovation actors, with diverse - sometimes conflicting - goals (e.g., [14]), the explicit advocacy of diverse perspectives and inputs in mission statements might enable organizations to create an identity that harnesses the various diverse inputs resulting from the convergence of organizations, products, and industries. Beyond that, since digital technology often requires pursuing multiple goals (e.g., [21]) "[...] an organization needs audiences to be present who value each" [20, p. 231]. Here, the presence of different interest groups with diverging values can help to find a balance between different perspectives by preventing one from dominating the other [48].

Our study is limited in several respects. First, our sample includes only companies from the IT industry. We focused on a single industry sector to control for variance across industry sectors, as recommended in existing literature [2], but therefore our results are only applicable to the context of the IT industry. Since incumbents that originated in the industrial era are fundamentally challenged by identity-changing technologies, this limitation provides many opportunities for future research. Second, our research is explorative in nature and only a first step towards better understanding how organizational identities are framed in an environment, which is increasingly shaped by digital technology. Thus, we hope to see future research to extend and test our findings with longitudinal data. Third, we built upon the established insights by Desmidt et al. [31] to deductively develop our initial coding guidelines. While a deductive approach allows us to stay closer to extant insights in literature, it might also resulted in a more narrow view during data analysis.

Despite these limitations, our findings allow us to make some recommendations for practitioners. When developing a mission statement, organizations should consider its implication on the overall organizational identity. Differentiating between the four different categories of Purpose, Strategic Boundaries, Value Propositions, and Value Statements [31] can help to identify important compo-

\begin{tabular}{|c|c|}
\hline Key Arguments & Research Questions for Future Research \\
\hline $\begin{array}{l}\text { Digital technology re- } \\
\text { quires organizations to } \\
\text { pursue multiple- } \\
\text { sometimes conflicting } \\
\text { - goals simultane- } \\
\text { ously. }\end{array}$ & $\begin{array}{l}\text { Under what circumstances, if any, can organizations not act in accordance with their own identity } \\
\text { without jeopardizing their own reputation? } \\
\text { How can an organizational identity and mission make it possible to pursue multiple - sometimes } \\
\text { contradictory - goals? } \\
\text { How can organizations promote an identity that is consistent with a "digital culture"? } \\
\text { How does the existence of multiple conflicting goals affect employees within an organization? How } \\
\text { does it affect customers? }\end{array}$ \\
\hline $\begin{array}{l}\text { Differences in the } \\
\text { framing of organiza- } \\
\text { tional identities with } \\
\text { regard to focus on } \\
\text { Purpose, Strategic } \\
\text { Boundaries, Value } \\
\text { Propositions, and } \\
\text { Value Statements. }\end{array}$ & $\begin{array}{l}\text { Under what circumstances, if at all, can organizations benefit from anchoring strategic boundaries } \\
\text { in their organizational identity? } \\
\text { If "broad identities" with few or no constraints are advantageous for identifying new technological } \\
\text { opportunities and imposing fewer constraints on an organization's behavior, are there advantages to } \\
\text { a narrower identity? If so, in what ways should an identity be restricted? } \\
\text { Are the differences observed in the IT industry representative for other industries? If not, what other } \\
\text { patterns exist and why are they different from those in the IT industry? }\end{array}$ \\
\hline $\begin{array}{l}\text { Mission statements } \\
\text { are a tool to manage } \\
\text { and frame an organi- } \\
\text { zations' } \\
\text { mission and identity. }\end{array}$ & $\begin{array}{l}\text { How can mission statements change the way organizations interpret digital technologies? } \\
\text { Which topics do exist within mission statements? How are they used across industries to frame or- } \\
\text { ganizational identity? } \\
\text { How can organizations proactively re-frame their identity and mission when unexpected technologi- } \\
\text { cal disruptions occur? }\end{array}$ \\
\hline
\end{tabular}


nents. Here, our results indicate that organizations benefit from anchoring a broad purpose and clear values in their mission statements but should refrain from specifying a specific industry or product. By doing so, organizations do not impose unnecessarily narrow restrictions on acceptable markets or products, thereby, remaining flexible towards new opportunities. Table 4 highlights our three key arguments and defines specific research questions for future research.

\section{Conclusion}

Digital technology is at the core of several phenomena such as digital transformation and digital innovation. To better understand how organizations manage

\section{References}

[1] P. F. Drucker, Management: Tasks, responsibilities, practices, HarperBusiness, New York, NY, 1974.

[2] M. Blair-Loy, A. S. Wharton, and J. Goodstein, "Exploring the Relationship between Mission Statements and Work-Life Practices in Organizations," Organization Studies, vol. 32, no. 3, pp. 427-450, 2011.

[3] D. Rigby and B. Bilodeau, "Management Tools \& Trends," Bain \& Company, 2018,

https://www.bain.com/insights/management-toolsand-trends-2017/.

[4] C. K. Bart, "Exploring the application of mission statements on the World Wide Web," Internet Research, vol. 11, no. 4, pp. 360-369, 2001.

[5] M. G. Grimes, T. A. Williams, and E. Y. Zhao, "Anchors Aweigh: The Sources, Variety, and Challenges of Mission Drift," Academy of Management Review, vol. 44, no. 4, pp. 819-845, 2019.

[6] E. P. Piening, T. O. Salge, D. Antons et al., "Standing Together or Falling Apart? Understanding Employees' Responses to Organizational Identity

Threats," Academy of Management Review, vol. 45, no. 2, pp. 325-351, 2020.

[7] F. R. David, "How Companies Define Their Mission," Long Range Planning, vol. 22, no. 1, pp. 9097, 1989.

[8] L. S. Williams, "The Mission Statement: A Corporate Reporting Tool With a Past, Present, and Future," Journal of Business Communication, vol. 45, no. 2, pp. 94-119, 2008.

[9] D. K. Basdeo, K. G. Smith, C. M. Grimm et al., "The impact of market actions on firm reputation," Strategic Management Journal, vol. 27, no. 12, pp. 1205$1219,2006$.

[10] B. R. Bartkus and M. Glassman, "Do Firms Practice What They Preach? The Relationship Between Mission Statements and Stakeholder Management," Journal of Business Ethics, vol. 83, no. 2, pp. 207216, 2008.

[11] G. Cheney, L. T. Christensen, C. Conrad et al., "Corporate Rhetoric as Organizational Discourse," in The the sometimes contradictory implications of digital technology, the present study has investigated differences about how organizations in the IT industry frame their identity and mission. Our results allow us to contribute to current literature by: (1) Identifying differences in the framing of organizational identities with regard to focus on Purpose, Strategic Boundaries, Value Propositions, and Value Statements. (2) Discussing the implications of our results on current literature concerned with 'digital phenomena'. (3) Outlining promising research questions for future research.

SAGE handbook of organizational discourse, D. Grant, Ed., pp. 79-104, SAGE, Los Angeles, 2008.

[12] J. A. Weiss and S. K. Piderit, "The Value of Mission Statements in Public Agencies," Journal of Public Administration Research and Theory, no. 2, pp. 192223, 1999.

[13] G. Vial, "Understanding Digital Transformation: A Review and a Research Agenda," The Journal of Strategic Information Systems, vol. 28, no. 2, pp. 118-145, 2019.

[14] K. Lyytinen, Y. Yoo, and R. J. Boland Jr., "Digital Product Innovation Within Four Classes of Innovation Networks," Information Systems Journal, vol. 26, no. 1, pp. 47-75, 2016.

[15] D. Seo, "Digital Business Convergence and Emerging Contested Fields: A Conceptual Framework," Journal of the Association for Information Systems, vol. 18, no. 19, pp. 687-702, 2017.

[16] R. J. Boland, K. Lyytinen, and Y. Yoo, "Wakes of Innovation in Project Networks: The Case of Digital 3-D Representations in Architecture, Engineering, and Construction," Organization Science, vol. 18, no. 4, pp. 631-647, 2007.

[17] D. Tilson, K. Lyytinen, and C. Sørensen, "Research Commentary - Digital Infrastructures: The Missing IS Research Agenda," Information Systems Research, vol. 21, no. 4, pp. 748-759, 2010.

[18] R. F. Ciriello, A. Richter, and G. Schwabe, "The Paradoxical Effects of Digital Artefacts on Innovation Practices," European Journal of Information Systems, vol. 28, no. 2, pp. 149-172, 2019.

[19] M. Tripsas, "Technology, Identity, and Inertia Through the Lens of "The Digital Photography Company"," Organization Science, vol. 20, no. 2, pp. 441-460, 2009.

[20] C. Varendh-Mansson, T. Wry, and A. Szafarz, "Anchors Aweigh? Then Time to Head Upstream: Why We Need to Theorize "Mission" Before "Drift"," Academy of Management Review, vol. 45, no. 1, pp. 230-233, 2020.

[21] F. Svahn, L. Mathiassen, and R. Lindgren, "Embracing Digital Innovation in Incumbent Firms: How Volvo Cars Managed Competing Concerns," MIS Quarterly, vol. 41, no. 1, pp. 239-253, 2017. 
[22] M. G. Grimes and T. A. Williams, "Beyond Hybridity: Accounting for the Values Complexity of All Organizations in the Study of Mission and Mission Drift," Academy of Management Review, vol. 45, no. 1, pp. 234-239, 2020.

[23] Y. Yoo, O. Henfridsson, and K. Lyytinen, "The New Organizing Logic of Digital Innovation: An Agenda for Information Systems Research," Information Systems Research, vol. 21, no. 4, pp. 724-735, 2010.

[24] O. Henfridsson and Y. Yoo, "The Liminality of Trajectory Shifts in Institutional Entrepreneurship," Organization Science, vol. 25, no. 3, pp. 932-950, 2014.

[25] Y. Yoo, R. J. Boland, K. Lyytinen et al., "Organizing for Innovation in the Digitized World," Organization Science, vol. 23, no. 5, pp. 1398-1408, 2012.

[26] H. C. Lucas and J. M. Goh, "Disruptive Technology: How Kodak Missed the Digital Photography Revolution," The Journal of Strategic Information Systems, vol. 18, no. 1, pp. 46-55, 2009.

[27] D. Campbell, P. Shrives, and H. Bohmbach-Saager, "Voluntary Disclosure of Mission Statements in Corporate Annual Reports: Signaling What and To Whom?," Business and Society Review, vol. 106, no. 1, pp. 65-87, 2001.

[28] C. H. Amato and L. H. Amato, "Corporate Commitment to Quality of Life: Evidence from Company Mission Statements," Journal of Marketing Theory and Practice, vol. 10, no. 4, pp. 69-87, 2002.

[29] S. Braun, J. S. Wesche, D. Frey et al., "Effectiveness of mission statements in organizations - A review," Journal of Management \& Organization, vol. 18, no. 4, pp. 430-444, 2012.

[30] J. A. Pearce and F. David, "Corporate Mission Statements: The Bottom Line," Academy of Management Perspectives, vol. 1, no. 2, pp. 109-115, 1987.

[31] S. Desmidt, A. Prinzie, and A. Decramer, "Looking for the Value of Mission Statements:: A Meta-Analysis of 20 Years of Research," Management Decision, vol. 49, no. 3, pp. 468-483, 2011.

[32] C. Kim and J.-H. Park, "The Global Research-andDevelopment Network and Its Effect on Innovation," Journal of International Marketing, vol. 18, no. 4, pp. 43-57, 2010.

[33] N. Shin, K. L. Kraemer, and J. Dedrick, "R\&D, Value Chain Location and Firm Performance in the Global Electronics Industry," Industry \& Innovation, vol. 16, no. 3, pp. 315-330, 2009.

[34] P. Mayring and T. Fenzl, "Qualitative Inhaltsanalyse," in Handbuch Methoden der empirischen Sozialforschung, N. Baur and J. Blasius, Eds., pp. 543556, Springer Fachmedien Wiesbaden, Wiesbaden, 2014.

[35] C. K. Bart, "A Comparison of Mission Statements and their Rationales in Innovative and Non-Innovative Firms," International Journal of Technology Management, vol. 16, 1-3, pp. 64-77, 1998.

[36] C. K. Bart, "Innovation, Mission Statements and Learning," International Journal of Technology Management, vol. 27, 6/7, pp. 544-561, 2004.
[37] O. Henfridsson, J. Nandhakumar, H. Scarbrough et al., "Recombination in the Open-ended Value Landscape of Digital Innovation," Information and Organization, vol. 28, no. 2, pp. 89-100, 2018.

[38] E. von Hippel, Democratizing Innovation, MIT Press, Cambridge Mass. u.a., 2006.

[39] S. Nambisan, K. Lyytinen, and Y. Yoo, “1. Digital Innovation: Towards a Transdisciplinary Perspective," in Handbook of Digital Innovation, S. Nambisan, K. Lyytinen, and Y. Yoo, Eds., pp. 2-12, Edward Elgar Publishing, Cheltenham, UK, Northampton, MA, 2020.

[40] J. Kallinikos, A. Aaltonen, and A. Marton, "The Ambivalent Ontology of Digital Artifacts," MIS Quarterly, vol. 37, no. 2, pp. 357-370, 2013.

[41] S. Nambisan, K. Lyytinen, A. Majchrzak et al., "Digital Innovation Management: Reinventing Innovation Management Research in a Digital World," MIS Quarterly, vol. 41, no. 1, pp. 223-238, 2017.

[42] J. C. Collins and J. I. Porras, "Building Your Company's Vision," Harvard Business Review, 1996.

[43] N. Berente, "5. Agile development as the root metaphor for strategy in digital innovation," in Handbook of Digital Innovation, S. Nambisan, K. Lyytinen, and Y. Yoo, Eds., pp. 83-96, Edward Elgar Publishing, Cheltenham, UK, Northampton, MA, 2020.

[44] O. Henfridsson, L. Mathiassen, and F. Svahn, "Managing Technological Change in the Digital Age: The Role of Architectural Frames," Journal of Information Technology, vol. 29, no. 1, pp. 27-43, 2014.

[45] E. von Hippel and G. von Krogh, "Crossroads - Identifying Viable "Need-Solution Pairs": Problem Solving Without Problem Formulation," Organization Science, pp. 207-221, 2016.

[46] A. C. Homan, D. van Knippenberg, G. A. van Kleef et al., "Bridging faultlines by valuing diversity: diversity beliefs, information elaboration, and performance in diverse work groups," The Journal of applied psychology, vol. 92, no. 5, pp. 1189-1199, 2007.

[47] S. Harvey, "Creative Synthesis: Exploring the Process of Extraordinary Group Creativity," Academy of Management Review, vol. 39, no. 3, pp. 324-343, 2014.

[48] W. K. Smith and M. L. Besharov, "Bowing before Dual Gods: How Structured Flexibility Sustains Organizational Hybridity," Administrative Science Quarterly, vol. 64, no. 1, pp. 1-44, 2019. 